\title{
Determinants of Credit Union Benefits to Members
}

\author{
Bradley A. Stevenson \\ Bellarmine University
}

Credit unions (CUs) are "not-for-profit" entities owned by members, providing benefits in the form of dividends and lower loan rates. Thus, CU performance is defined by the benefits provided to members. Previous theory suggests the percent dividend return per share and the difference between interest earned on loans and interest and dividends paid on shares and deposits are measures of member benefits. The findings indicate benefits depend on increased efficiency, increasing competitiveness of the CU, less noninterest income and more focus on lending, larger asset size, more monitoring by uninsured depositors, higher risk, and better screening and monitoring of borrowers.

Keywords: credit unions, credit union performance

\section{INTRODUCTION}

In the U.S., when most people think of a financial institution, they usually think of a bank. However, other institutions are also important vehicles for saving and borrowing. In this paper, credit union (CU) performance is examined to determine the characteristics that allow CUs to maximize the benefit they provide to their members. Two distinct features differentiate credit unions from commercial banks. First, members of a credit union must have a "common bond". This bond is usually an affiliation to a certain group (i.e. teachers' union, school district) or an affiliation with a geographic location (i.e. people who live, worship, or work in a certain county). Second, much to the consternation of bankers, credit unions are tax-exempt. The members of the credit union act as a cooperative where members (who act as owners) have shares in the credit union (which are like deposits). The tax-exemption helps credit union members, in theory, receive higher rates on their shares and lower rates on their loans. The results of this paper show that benefits provided are higher in CUs that have increased efficiency, higher competitiveness of the CU, less use of non-interest income and more of a focus on lending, larger asset size, more monitoring by uninsured depositors, take more risks, and are better screeners and monitors of their borrowers.

Credit unions are unique and distinct from banks while also providing many of the same services as banks, the major ones being taking deposits and making loans. Because of the common bond requirement, most credit unions are small. As of June 2017, there are 5,812 CUs with an average asset size of $\$ 235.2$ million. While they are small, as of June 2017, CUs have a total membership of over 110.6 million members, roughly over one-third of the U.S. population. For the same period, the number of banks is 5,795 with average assets per institution of $\$ 2,960$ million. Both banks and CUs have been decreasing in numbers over the last several years while becoming larger in terms of asset size. While both types of institutions have been growing, the three year average for growth in assets and loans for CUs has been $7.4 \%$ and $10.6 \%$ respectively. For the same period, banks' three year average for growth in assets and loans has been $3.8 \%$ and $5.3 \%$ respectively. This is not to say that CUs are performing better than banks. 
What is highlighted here is CUs serve a large portion of the U.S. population and their growth implies an even more important role in the U.S. economy going forward. ${ }^{1}$

While credit unions remain an important component of our financial system, the amount of research devoted to CUs is small relative to the amount of research exploring banks. Perhaps this lack of attention is due to their size or perhaps the assumption is that CUs essentially operate as small banks and, therefore, separate research on CUs is not necessary. For the reasons given above, it is clear CUs are an important component of the financial system and, because of their non-profit status and goals, are fundamentally different from banks and, because of this, warrant research into CUs as a separate, distinct institution.

This introduction is followed by a literature review in Section 2. Section 3 presents data and methodology while Section 4 describes the empirical results. Section 5 concludes.

\section{LITERATURE REVIEW}

Smith, Cargill, and Meyer (1981) discuss how credit unions (CUs) are fundamentally different from for-profit banks and discuss two main reasons why typical thinking on financial intermediaries cannot be applied directly to credit unions. First, as mentioned in Section 1, CUs are like a cooperative where the members are both owners and customers. In this setup, profit maximization is not necessarily the goal of the owners. Second, the borrowers and savers at CUs are members. Thus, they are the suppliers and demanders of funds. Smith, et.al. (1981) propose the difficulty for CUs is the CU cannot hope to simultaneously maximize its dividend rate and minimize its rate on loans. The two goals are at odds. On the other hand, in earlier research, Taylor (1971) demonstrates that maximizing member benefit is the optimal behavior by a CU and they can do this by minimizing the difference between the average loan and savings rates. In cases where the CU treats borrowers and savers equally in a riskless setting, Smith, et.al. (1981) show that borrowers and savers are treated equally with benefits of the CU provided equally to both. They do show that when risk is introduced that the CU will want to increase its surplus which would entail charging higher rates on loans and giving lower dividends. In this case, the savings on loan rates and the rate paid on dividends is not a breakeven result.

While empirical research on CUs is not as plentiful as it is on banks, there is an existing line of research. Much of the early literature focused on cost efficiency. Murray and White (1980) is an example. They look at cost minimization a way to measure CU performance and examine the impact of technology and returns to scale finding that: CUs realize increasing returns to scale, that technology strongly affects the average cost curve of the CU, some CUs adopted technology that did not benefit their cost structure, and that expansion to multiple branches was beneficial in rxeducing costs. However, Smith (1984) argues that looking at cost efficiency is incorrect as the assumptions of doing so, such as a fixed exogenous level of output, are faulty. In the model, Smith ends up focusing on gains to members through lower loan rates and higher rates on saving. This seems similar to what Taylor (1971) proposes.

Frame, Karels, and McClatchey (2003) examine if the tax-exempt structure of credit unions is used to benefit members by comparing CUs to mutual thrifts. They find that while CUs whose common bond is residential tend to shift benefits away from members and towards management, those with occupational and associational bonds are more cost-efficient, benefiting members. Also looking at efficiency, Wheelock and Wilson (2013) find that cost productivity fell across CUs during the time period they examined from 1989 to 2006 . They speculate that proximity to customers and location have eroded as advantages over time due to changes in information technology.

As time has passed, CUs have gained access to products and services that previously only been provisioned by other financial institutions and, at the same time, CUs have benefited from looser restraints on the common bond requirement. Esho, Kofman, and Sharpe (2005) find that increased diversification, in terms of the percent of revenue derived from fees, increases risk and lowers returns in CUs in Australia. They also find that scale economies are associated with lower risk and higher returns. Wilcox (2006) has similar findings on asset size in that large CUs outperform small CUs across different measures of performance. Later, Wheelock and Wilson (2011) show increasing returns to scale for U.S. CUs examining a cost relationship that accounts for high rates to member savers and lower loan rates to 
member-borrowers. Goddard, McKillop, and Wilson (2008a) look at the effects of non-interest sources of income, which diversified revenues, from 1993-2004. Looking at risk-adjust and non-risk adjusted ROA and ROE as performance measures, they found that small CUs did not benefit from increased non-interest income activities while there is some benefit to larger CUs. On the other hand, Malikov, Zhao, and Kumbhakar (2017) find that diversified credit unions enjoy significant economies of diversification. Goddard, McKillop, and Wilson (2008b) find that charter types and other competitive repositioning of CUs are not beneficial and that other factors such as management and asset portfolios likely have more to do with CU performance.

Given the previous empirical literature studying CU performance, how does this paper extend the literature? One, this paper uses data from 2000 to 2015, looking at both data during the financial crisis and around it to examine if performance under stress is different than performance in a more "normal" environment. This time period also differs in that CUs are much more like banks today given the range of products and services they offer. As noted in previous literature, CUs have much more flexibility during this period due to the relaxation of common bond requirements. Two, this paper looks at two different measures of benefits to measure performance. The first measure is the dividend percent return to shareholders. If Smith et.al. (1981) are correct and borrowers and savers are treated equally with benefits, dividend performance should approximate benefits given to borrowers as well. Thus, just looking at the dividend percent return can give us an approximation of $\mathrm{CU}$ benefits provided to both savers and borrowers. As advocated by Taylor (1971), the second measure is the difference between the return earned on lending less the return paid on shares and deposits. The smaller the difference, the more benefits are being provided to both savers and lenders of the CU.

\section{DATA AND METHODOLOGY}

\section{Data and Hypotheses on Variable Relationships}

The data in this study is drawn from the National Credit Union Administration (NCUA) in the period from 2000 to 2015 from Call Report Form 3300. Like bank call reports, the CU call report contains information on the CU's statement of financial condition (i.e. balance sheet) and statement of income and expense (i.e. income statement). Other items within the call report have information related to the operations of the CU such as the number of members, derivative positions, loan and deposit maturities, calculation of capital adequacy, etc.

While the number of CUs has been declining, the number of CUs is still large partly due to the common bond requirement which limits expansion. For the 16-year period covered by this study, there are initially 131,121 observations. In the final analysis, a lag of the dependent variable is used in the regression so the first year of data for each $\mathrm{CU}$ is removed. This brings the number of observations to 119,953. Some observations were also removed due to some missing data and the removal of outliers. This drops the number of observations to $97,956{ }^{2,3}$

As a means to measure the level of benefits provided to CU members, two measures were selected. The first is the dividend percent return, DPR. DPR is calculated as Dividends on Shares divided by the dollar amount of Total Shares. The second is the difference, DIFF, between the rate of interest received on loans (Interest on Loans less Interest Refunded divided by Total Loans and Leases) and the interest paid on shares and deposits (Dividends on Shares plus Interest on Deposits divided by Total Shares and Deposits). Table 1 shows that the mean DPR is about $1.50 \%$ with a median of about $1.34 \%$ while the mean DIFF is about $5.55 \%$ with a median of $5.35 \%$. The proposal is that CUs with higher DPR and lower DIFF provide more benefits to their members. Lower DIFF provides higher member benefits because the $\mathrm{CU}$ is maximizing payments on members' shares and charging as little as possible on member loans. Thus, a smaller DIFF is providing both borrowers and savers more benefits. In the regressions, a lag of the dependent variable (either DPR or DIFF) is included as one of the independent variables. Since the best predictor for what DIFF or DPR might be at time $t$ is what DIFF or DPR was at time $t-1$, the lagged dependent variable is included. 
TABLE 1

DESCRIPTIVE STATISTICS

\begin{tabular}{|c|c|c|c|c|c|c|c|}
\hline Variables & Maximum & Minimum & Mean & Median & $\begin{array}{l}\text { Standard } \\
\text { Deviation }\end{array}$ & $\begin{array}{l}25^{\text {th }} \\
\text { Percentile }\end{array}$ & $\begin{array}{l}75^{\text {th }} \\
\text { Percentile }\end{array}$ \\
\hline ROA & $9.69 \%$ & $-9.84 \%$ & $0.57 \%$ & $0.54 \%$ & $0.67 \%$ & $0.21 \%$ & $0.92 \%$ \\
\hline DPR & $12.63 \%$ & $0.00 \%$ & $1.50 \%$ & $1.34 \%$ & $1.08 \%$ & $0.61 \%$ & $2.19 \%$ \\
\hline DIFF & $12.00 \%$ & $-1.86 \%$ & $5.55 \%$ & $5.35 \%$ & $1.57 \%$ & $4.50 \%$ & $6.35 \%$ \\
\hline ER & 1.00 & -0.95 & 0.80 & 0.81 & 0.12 & 0.73 & 0.88 \\
\hline PerCap & $100.00 \%$ & $0.00 \%$ & $41.26 \%$ & $40.00 \%$ & $28.23 \%$ & $14.82 \%$ & $64.05 \%$ \\
\hline LnAssets & 25.02 & 9.46 & 16.77 & 16.73 & 1.86 & 15.56 & 17.98 \\
\hline Assets & $\$ 73.28 \mathrm{~B}$ & $\$ 12,855$ & $\$ 116.94 \mathrm{M}$ & $\$ 18.35 \mathrm{M}$ & $\$ 697.86 \mathrm{M}$ & $\$ 5.70 \mathrm{M}$ & $\$ 64.08 \mathrm{M}$ \\
\hline NWR & $35.00 \%$ & $0.94 \%$ & $13.26 \%$ & $11.98 \%$ & $5.02 \%$ & $9.67 \%$ & $15.52 \%$ \\
\hline NIIPortion & $50.00 \%$ & $-28.41 \%$ & $14.57 \%$ & $13.44 \%$ & $11.17 \%$ & $4.79 \%$ & $22.31 \%$ \\
\hline UninsDep & $16.00 \%$ & $0.00 \%$ & $2.57 \%$ & $1.27 \%$ & $3.29 \%$ & $0.00 \%$ & $4.02 \%$ \\
\hline OneMinTL & $99.89 \%$ & $-8.89 \%$ & $42.11 \%$ & $40.64 \%$ & $17.58 \%$ & $29.01 \%$ & $53.78 \%$ \\
\hline Risk & $6.99 \%$ & $0.00 \%$ & $0.93 \%$ & $0.58 \%$ & $1.06 \%$ & $0.26 \%$ & $1.19 \%$ \\
\hline Recover & $1.96 \%$ & $-2.50 \%$ & $-0.32 \%$ & $-0.21 \%$ & $0.39 \%$ & $-0.44 \%$ & $-0.07 \%$ \\
\hline
\end{tabular}

ROA is net income divided by total assets. The dividend return per share examined is the total dividend paid on shares divided by the total dollar amount of shares. ER is the Efficiency Ratio which equals Non-Interest Expense divided by the sum of Non-Interest Income and Net Interest Income. PerCap stands for Percent Captured and is the number of $\mathrm{CU}$ members divided by the number of potential $\mathrm{CU}$ members. LnAssets is the log of the dollar amount of assets at the CU. NWR is the Net Worth Ratio, the ratio of the net worth of the $\mathrm{CU}$ to the total assets of the credit union. NIIPortion is the portion of NonInterest Income to total income. UninsDep is the ratio of total uninsured shares and deposits to total assets. OneMinTL is the amount of assets outside of total loans and leases divided by total assets. Risk is the amount of delinquent loans divided by total assets for the CU. Recover is year-to-date recoveries of loan losses less the year-to-date charge offs of loans divided by total assets.

Other variables used in the analysis were selected based on previous theory or empirical research in either banking, credit unions, or both. While the argument is made above that CUs are unique and different from banks, they do perform a similar function and do directly compete with each other.

The first explanatory variable used is the Efficiency Ratio, ER. ER is defined as the Non-Interest Expense divided by the sum of Non-Interest Income and Net Interest Income where higher values indicate lower efficiency. While ER does not appear to be directly used in previous studies, Akhigbe, et.al. (2017) and other studies do show that increases in spending on salary and benefits per employee are related to lower profit efficiency by banks which would be similar to a higher ER as used here. As ER increases, more is being spent on non-interest expense and, thus, there is less left to pay members on their shares. Thus, the expected relationship between ER and DPR is negative. As ER increases (i.e. as CUs become more inefficient), the expectation is that DPR will fall. In the regression analysis, ER is only used to examine DPR and not DIFF. The reason is that, if Non-Interest Expense and Non-Interest Income are held constant and if Net Interest Income becomes smaller, ER will rise indicating less efficiency. Since smaller Net Interest Income will be highly correlated with smaller DIFF, interpreting these results would be difficult.

The second explanatory variable is PerCap which stands for Percent Captured and is the number of CU members divided by the number of potential CU members. As shown in Table 1, the mean percent captured is $41.26 \%$ with a standard deviation of $28.23 \%$. Thus, there is a significant variation in how much of their potential market CUs capture. It is common in the banking literature to include the Herfindahl-Hirschman Index (HHI) as a proxy for market concentration/competition calculated by 
summing the square of the share of deposits for each bank within a defined region. For the purposes of this paper, the competition faced by a CU is also considered as a factor that may affect the level of benefits provided to members. CUs face competition from any institution that provides the same services they do including banks and other CUs. A high PerCap could occur for two reasons. First, it could be that few competitors exist in the market in which the CU operates. If this is the case, it could be expected that the $\mathrm{CU}$ is inefficient, passing along fewer benefits to its members. Second, it could be that the CU is competitive with other financial institutions in its market and therefore, has captured a high number of its potential members. In this case, the expectation is that high levels of PerCap should be associated with higher levels of benefits (i.e. higher DPR and lower DIFF). As CUs become more competitive, with other financial institutions and CUs, they take a larger share of their market (i.e. higher PerCap). The expectation is that they will do so by providing greater benefit to their members. Relatedly, Fried, Lovell, and Vanden Eeckaut (1993) show that by capturing more of their potential members, CUs can improve their performance. The expectation in this paper then will reflect the findings of Fried, et.al. (1993) in that where the CU captures a high level of their potential members, PerCap should have a positive association DPR and a negative association with DIFF. If this expectation is not supported and a high PerCap reflects few competitors in the market allowing the $\mathrm{CU}$ to be inefficient, PerCap could have a negative association with DPR and a positive association with DIFF.

LnAssets is the log of the Total Assets of the CU. While not a direct measure of economies of scale, larger values of LnAssets should be correlated to increasing economies of scale. As Esho, Kofman, and Sharpe (2005) note, greater economies of scale correspond to higher returns for CUs. As can be seen in Table 1 , there are a few very large CUs with a median size of $\$ 18.35$ million and with the $25^{\text {th }}$ percentile being $\$ 5.70$ million and the $75^{\text {th }}$ percentile being $\$ 64.08$ million. In relation to banks where banks with less than $\$ 1$ billion are classified as "small", CUs would be considered small. However, even with the overall smaller size, with increasing size and greater efficiency, the CU should be able to pass that benefit onto its members in the form of higher DPR and lower DIFF.

Next is the Net Worth Ratio (NWR). NWR is calculated by taking the Total Net Worth of the CU and dividing it by Total Assets. This ratio represents the leverage and, thus, risk faced by the CU where smaller values indicate higher leverage and vice versa. While there are regulations that require a certain level of Net Worth within a CU, as can be seen in Table 1, there is variation in NWR. While the mean is about $13.26 \%$ and the median is about $11.98 \%$, the $25^{\text {th }}$ percentile is at $9.67 \%$ and the $75^{\text {th }}$ percentile is at $15.52 \%$. If increased leverage and risk (i.e. lower NWR) result in higher returns and those benefits are passed on to members, the expectation is that NWR will be positively related to DIFF and negatively related to DPR. Here, no expectation is given to the sign of the coefficient for NWR. NWR just serves to control for the risk of leverage amongst the CUs.

NIIPortion is defined as the portion of Non-Interest Income to total income. In the banking literature, while some studies find increasing non-interest income (NII) to benefit banks, others do not. For instance, Baele, De Jonghe, and Vander Vennet (2007) show that higher levels of NII increase the franchise value of European banks. On the other hand, Stiroh and Rumble (2006) show that increasing the diversification of revenue actually makes banks perform worse in terms of profits. Stiroh (2004) and Akhigbe and Stevenson (2010) show that increases levels of NII have a negative effect on the profit efficiency of bank holding companies. Goddard, McKillop, and Wilson (2008a) also show that diversification through noninterest income is not beneficial to CUs and should not be pursued. The expectation of this paper is that increases in NIIPortion will not benefit CUs and that increases in NIIPortion will be associated with lower DPR and higher DIFF. Levels of NIIPortion among the CUs in the sample vary fairly widely with the median at $13.44 \%$, the $25^{\text {th }}$ percentile at $4.79 \%$ and the $75^{\text {th }}$ percentile at $22.31 \%$.

The sixth explanatory variable used is the ratio of total uninsured shares and deposits to total assets, UninsDep. As Baer and Brewer (1986) note, increased levels of uninsured deposits increase the discipline on bank management, otherwise known as market discipline. In Baer and Brewer's (1986) study, this discipline increases banks' incentive to control risk. Thus, in this study, even though publicly traded securities will not impose market discipline on CUs, uninsured deposits will. As may be expected, however, the amount of uninsured deposits is small on average for CUs with a mean of $2.57 \%$ and a 
median of $1.27 \%$. Given that the goal of the member/owners of the $\mathrm{CU}$ is to provide benefits to the members, the expectation is that increasing levels of UninsDep will be positively related to DPR and negatively related to DIFF.

One minus total loans, OneMinTL, is the amount of assets outside of total loans and leases divided by total assets. OneMinTL is included to capture the "quiet life hypothesis". According to this hypothesis, financial institutions like CUs in less competitive markets may only choose loans with the highest rewardto-risk-ratio and hence limit their lending. This may result in a less-than-optimal portfolio of loans. In other words, CUs that hold more assets in non-loan assets will perform more poorly than CUs that optimally invest in more loans. If $\mathrm{CU}$ behavior reflects this notion, the hypothesis for OneMinTL is that the coefficient will be negative for DPR and positive for DIFF. This would mirror the finding in Akhigbe and McNulty (2005) who found a similar result for small and medium-sized banks. The mean for OneMinTL is $42.11 \%$ which means approximately $42.11 \%$ of assets are in assets besides loans. The $25^{\text {th }}$ percentile is $29.01 \%$ and the $75^{\text {th }}$ percentile is $53.78 \%$.

Next, Risk is the amount of delinquent loans divided by total assets for the CU. Like NWR, this measures risk for the CU but, instead of measuring risk due to financial leverage, it measures credit risk of the CU. The mean value for Risk is $0.93 \%$. The $25^{\text {th }}$ percentile is $0.26 \%$ while the $75^{\text {th }}$ percentile is $1.19 \%$. Higher values indicate higher relative risk (a larger amount of delinquent loans). Generally, risk and reward go hand in hand so it could be hypothesized that the riskier the $\mathrm{CU}$, the better returns for their members. However, a higher level of risk could also indicate poor lending decisions and practices which may hinder benefits to members. In banking studies such as Akhigbe, McNulty, and Stevenson (2017), higher levels (i.e. more risk) of risk were found to correspond with lower levels of profit efficiency. Thus, the hypothesis of this paper for Risk is that it will have a negative relationship with DPR and a positive relationship with DIFF.

The last explanatory variable is Recover which is year-to-date recoveries of loan losses less the yearto-date charge offs of loans divided by total assets. As shown in Ferguson and Stevenson (2014), higher recovery rates on the part of banks indicate greater monitoring and screening skill by the lender. Better monitoring and screening of borrowers should lead to better performance on the CUs loan portfolio and, therefore, the hypothesis is that Recover will be positively related to DPR and negatively related to DIFF. In other words, better monitoring and screening CUs should provide more benefits to members.

Three types of control variables are included as well. First, StateIns and StateUnins, are dummy variables that equal one if the $\mathrm{CU}$ is state-chartered and does have insurance or does not have insurance, respectively. While, not one of the main objectives of this paper, Karels and McClatchey (1999) do show that insured credit unions are better capitalized and more liquid than uninsured CUs. However, they do not find a change in risk in CUs due to the presence of deposit insurance. Year dummies are also included with the base year being 2001. Finally, dummies for the regions designated by CUNA are included where Regions 1 is the base.

\section{Methodology}

The goal of the paper is to determine what CU characteristics enhance or deter the CU's ability to provide benefits to its members. As proposed above, this paper measures the benefits provided to members with the dividend return per share, DPR, where higher DPR equals more benefits provided to members, and with the difference between lending rates and deposit and share rates, DIFF, where lower DIFF equals more benefits provided to members. Three regressions are performed for each dependent variable (DPR and DIFF). The first regression uses all years from 2001 to 2015, while the second looks at the years surrounding the financial crisis, 2001 to 2007 and 2010 to 2015. The third regression focuses on the years around the heart of the financial crisis, 2008 and 2009. These different periods are examined because of the unusual nature of the financial environment around the crisis and the unusual steps in the financial sector taken by the government during the crisis. To test the hypotheses above, the following equation is estimated: 
DPR or DIFF $=\mathrm{f}($ ER $($ DPR only), Lag of DPR or DIFF, PerCap, LnAssets, NWR, NIIPortion, StateIns, StateUnins, UninsDep, OneMinTL, Risk, Recover, Region, Year)

where

$\mathrm{DPR}=$ the total dividend paid on shares divided by the total dollar amount of shares;

DIFF $=$ the rate of interest received on loans (Interest on Loans less Interest Refunded divided by Total Loans and Leases) less the interest paid on shares and deposits (Dividends on Shares plus Interest on Deposits divided by Total Shares and Deposits);

LagDPR or LagDIFF = DPR or DIFF from the previous year;

$\mathrm{ER}=$ Non-Interest Expense divided by the sum of Non-Interest Income and Net Interest Income;

PerCap = the number of CU members divided by the number of potential CU members;

LnAssets $=$ the $\log$ of the Total Assets of the CU;

NWR = the Net Worth Ratio (NWR) where NWR is calculated by taking the Total Net Worth of the CU and dividing it by Total Assets;

NIIPortion $=$ the portion of Non-Interest Income to total income;

StateIns $=1$ if the CU is state-chartered and has insurance;

StateUnins $=1$ if the $\mathrm{CU}$ is state-chartered and has no insurance;

UninsDep $=$ the ratio of total dollars of uninsured shares and deposits to total assets;

OneMinTL $=$ the amount of assets outside of total loans and leases divided by total assets;

Risk $=$ the amount of delinquent loans divided by total assets for the CU;

Recover $=$ the year-to-date recoveries of loan losses less the year-to-date charge offs of loans divided by total assets;

Region $=1$ if falls into a region defined by CUNA where Region 1 is the base;

Year $=1$ for the year in which the observation is taken where 2001 is the base year.

\section{EMPIRICAL RESULTS}

\section{Factors Affecting DPR for the Full Sample Period}

Table 2 shows the results for the first regression using the entire length of the sample from 2000 to 2015 where DPR is used to measure benefits to CU members. ${ }^{4}$ Recall that DPR is used to measure benefits to members because, if Smith et.al. (1981) are correct and borrowers and savers are treated equally with benefits, dividend performance should approximate benefits given to borrowers as well. Thus, just looking at the dividend percent return can give us an approximation of CU benefits provided to both savers and borrowers. 
TABLE 2

FACTORS IMPACTING THE DIVIDEND PERCENT RETURN, DPR, 2001 - 2015

\begin{tabular}{|c|c|c|c|c|}
\hline Variable & Coefficient & T-Value & HCCM T-Value & VIF \\
\hline Intercept & 0.00926 & 35.25 & 2.32 & 0 \\
\hline LagDPR & 0.64726 & 356.04 & 6.40 & 2.647 \\
\hline ER & -0.00269 & -21.57 & -2.17 & 1.211 \\
\hline PerCap & 0.00048 & 8.27 & 2.82 & 1.332 \\
\hline LnAssets & 0.00011 & 9.38 & 2.42 & 2.274 \\
\hline NWR & -0.0000055 & -1.69 & -0.74 & 1.349 \\
\hline NIIPortion & -0.00495 & -28.27 & -2.32 & 1.923 \\
\hline StateIns & -0.00089 & -28.50 & -2.59 & 1.167 \\
\hline StateUnins & -0.00022 & -1.91 & -1.19 & 1.039 \\
\hline UninsDep & 0.00750 & 13.77 & 6.45 & 1.615 \\
\hline OneMinTL & -0.00231 & -25.53 & -6.58 & 1.273 \\
\hline Risk & 0.01802 & 11.98 & 3.38 & 1.284 \\
\hline Recover & 0.06007 & 15.08 & 13.12 & 1.221 \\
\hline REG2 & 0.00046 & 9.23 & 3.01 & 1.758 \\
\hline REG3 & 0.00086 & 17.74 & 2.49 & 1.914 \\
\hline REG4 & 0.00075 & 16.41 & 2.73 & 2.108 \\
\hline REG5 & 0.00026 & 5.14 & 1.92 & 1.712 \\
\hline REG6 & 0.00014 & 1.62 & 0.64 & 1.336 \\
\hline REG8 & 0.00030 & 0.20 & 0.81 & 1.003 \\
\hline 2002 & -0.00671 & -99.80 & -19.10 & 1.807 \\
\hline 2003 & -0.00659 & -91.64 & -5.19 & 1.997 \\
\hline 2004 & -0.00508 & -65.02 & -2.7 & 2.255 \\
\hline 2005 & -0.00153 & -18.91 & -0.71 & 2.363 \\
\hline 2006 & 0.00175 & 21.92 & 0.9 & 2.237 \\
\hline 2007 & 0.00195 & 25.07 & 1.31 & 2.020 \\
\hline 2008 & -0.00283 & -35.85 & -2.62 & 1.779 \\
\hline 2009 & -0.00649 & -79.83 & -5.01 & 1.846 \\
\hline 2010 & -0.00658 & -75.27 & -3.51 & 1.918 \\
\hline 2011 & -0.00657 & -72.74 & -2.93 & 2.075 \\
\hline 2012 & -0.00646 & -69.7 & -2.6 & 2.198 \\
\hline 2013 & -0.00628 & -65.95 & -2.4 & 2.210 \\
\hline 2014 & -0.00613 & -63.71 & -2.25 & 2.259 \\
\hline 2015 & -0.00602 & -62.08 & -2.17 & 2.270 \\
\hline & \multicolumn{4}{|c|}{$\mathrm{N}=97,956$} \\
\hline & \multicolumn{4}{|c|}{$\mathrm{R}^{2}=0.8323$} \\
\hline & \multicolumn{4}{|c|}{ F-Value $=15,189.40$} \\
\hline \multicolumn{5}{|c|}{$\begin{array}{l}\text { The dividend percent return, DPR, examined is the total dividend paid on shares divided by the } \\
\text { total dollar amount of shares. ER is the Efficiency Ratio which equals Non-Interest Expense } \\
\text { divided by the sum of Non-Interest Income and Net Interest Income. PerCap stands for Percent } \\
\text { Captured and is the number of CU members divided by the number of potential CU members. } \\
\text { LnAssets is the log of the dollar amount of assets at the CU. NWR, Net Worth Ratio, is the ratio } \\
\text { of the net worth of the CU to the total assets of the CU. NIIPortion is the portion of Non-Interest } \\
\text { Income to total income. StateIns is a dummy variable equal to one if the CU is state-chartered and } \\
\text { federally insured. StateUnins is a dummy variable equal to one if the CU is state-chartered and not } \\
\text { federally insured. All other CUs are federally chartered and insured. UninsDep is the ratio of total }\end{array}$} \\
\hline
\end{tabular}


uninsured shares and deposits to total assets. OneMinTL is the amount of assets outside of total loans and leases divided by total assets. Risk is the amount of delinquent loans divided by total assets for the CU. Recover is year-to-date recoveries of loan losses less the year-to-date charge offs of loans divided by total assets. REG1, REG2, etc. are dummy variables for geographic regions used by CUNA where the base region is REG1. Year dummies $(2002,2003$, etc.) are equal to one for the year in which the data point is drawn from and zero otherwise where 2001 is the base year. The HCCM T-Value column provides t-values using Heteroscedasticity Consistent Covariance Matrix (HCCM) Estimation. This procedure is done in White (1980).

First, as hypothesized, ER is significant with a negative coefficient. This indicates that as the CU becomes less efficient, spending more of its resources on non-interest expense, it decreases the level of benefits to its members. Second, the coefficient on PerCap is positive and significant which matches the expectation that more competitive CUs will provide more benefits to their members as in Fried, Lovell, and Vanden Eeckaut (1993) who show that by capturing more of their potential members, CUs can improve their performance. Also, the lag of DPR is positive and has a very high t-stat indicating that the DPR from the previous period has a strong influence on the DPR for the current period.

Next, LnAssets is both positive and significant indicating that larger CUs are associated with increased benefits to members in the form of DPR. While NWR is negative and significant at the $10 \%$ level, the coefficient is very small and looking at the HCCM t-stat it appears to be not significant. On the other hand, NIIPortion has a negative and significant coefficient indicating that increased levels of noninterest income do not benefit CU members in the form of higher DPR which supports the expectation of this paper and concurs with the results of Akhigbe and Stevenson (2010) and Goddard, McKillop, and Wilson (2008a).

UninsDep, as expected, has a positive, significant coefficient. As Baer and Brewer (1986) suggest, increased discipline from uninsured depositors, absent external market discipline from publicly traded securities, acts to discipline management to perform in the interest of the owners of the CU, which in this case are the CU's members.

Next, while the expectation for OneMinTL, in line with Akhigbe and McNulty (2005), is supported with a negative, significant coefficient, the expectation is not supported for Risk with a positive, significant coefficient. For OneMinTL, where lower values equate to a more optimal mix of assets leaning toward revenue-generating loans, the negative coefficient indicates that when fewer assets are invested in loans, the lower the benefit provided to $\mathrm{CU}$ members. For Risk, in line with Akhigbe, McNulty, and Stevenson (2017), the hypothesis is that a higher level of risk in the form of more delinquent loans would also indicate poor lending decisions and practices which may hinder benefits to members. The results indicate otherwise, that a higher level of risk is associated with higher levels of DPR.

Finally, Recover has a positive, significant coefficient as expected which supports the expectation that better monitoring and screening of borrowers should lead to better performance on the CUs loan portfolio. Thus, better monitoring and screening CUs provide more benefits to members in terms of DPR.

\section{Factors Affecting DPR for the Non-crisis and Crisis Periods}

For the two subgroups examined, the only significant difference is for the crisis period. In the full sample and in the non-crisis period, NIIPortion is negative and significant. However, in the crisis period, NIIPortion is still negative but is not even close to significant. Thus, while the increased levels of noninterest income decrease benefits to members in the whole sample and in the non-crisis period, during the crisis this increased exposure does not matter. 
TABLE 3

FACTORS IMPACTING THE DIVIDEND PERCENT RETURN, DPR, 2001 - 2007, 2010 - 2015

\begin{tabular}{|c|c|c|c|c|}
\hline Variable & Coefficient & T-Value & HCCM T-Value & VIF \\
\hline Intercept & 0.00972 & 34.02 & 2.05 & 0 \\
\hline LagDPR & 0.63310 & 315.18 & 5.29 & 2.850 \\
\hline ER & -0.00291 & -21.41 & -2.09 & 1.216 \\
\hline PerCap & 0.00053 & 8.41 & 2.72 & 1.334 \\
\hline LnAssets & 0.00012 & 9.38 & 2.61 & 2.308 \\
\hline NWR & -0.000003 & -0.90 & -0.52 & 1.337 \\
\hline NIIPortion & -0.00558 & -29.13 & -2.35 & 1.959 \\
\hline StateIns & -0.00093 & -27.37 & -2.46 & 1.161 \\
\hline StateUnins & -0.00021 & -1.70 & -1.12 & 1.038 \\
\hline UninsDep & 0.00801 & 13.39 & 6.09 & 1.620 \\
\hline OneMinTL & -0.00225 & -22.98 & -5.58 & 1.268 \\
\hline Risk & 0.01864 & 11.32 & 3.01 & 1.286 \\
\hline Recover & 0.06189 & 14.06 & 11.92 & 1.205 \\
\hline REG2 & 0.00046 & 8.41 & 2.75 & 1.766 \\
\hline REG3 & 0.00091 & 17.23 & 2.41 & 1.911 \\
\hline REG4 & 0.00081 & 16.22 & 2.76 & 2.104 \\
\hline REG5 & 0.00029 & 5.25 & 2.06 & 1.719 \\
\hline REG6 & 0.00017 & 1.89 & 0.71 & 1.360 \\
\hline REG8 & 0.00029 & 0.19 & 0.74 & 1.003 \\
\hline 2002 & -0.00676 & -98.69 & -15.94 & 1.789 \\
\hline 2003 & -0.00677 & -91.49 & -4.47 & 2.015 \\
\hline 2004 & -0.00534 & -65.90 & -2.39 & 2.315 \\
\hline 2005 & -0.00183 & -21.72 & -0.71 & 2.445 \\
\hline 2006 & 0.00148 & 17.79 & 0.63 & 2.304 \\
\hline 2007 & 0.00174 & 21.64 & 0.98 & 2.057 \\
\hline 2010 & -0.00682 & -75.28 & -3.06 & 1.971 \\
\hline 2011 & -0.00685 & -72.91 & -2.57 & 2.153 \\
\hline 2012 & -0.00678 & -69.97 & -2.29 & 2.296 \\
\hline 2013 & -0.00661 & -66.35 & -2.12 & 2.317 \\
\hline 2014 & -0.00648 & -64.23 & -2.00 & 2.375 \\
\hline 2015 & -0.00637 & -62.69 & -1.93 & 2.388 \\
\hline \multicolumn{5}{|c|}{$\mathrm{N}=86,243$} \\
\hline & \multicolumn{4}{|c|}{$\mathrm{R}^{2}=0.8336$} \\
\hline & \multicolumn{4}{|c|}{ F-Value $=14,394.90$} \\
\hline \multicolumn{5}{|c|}{$\begin{array}{l}\text { The dividend percent return, DPR, examined is the total dividend paid on shares divided by the total } \\
\text { dollar amount of shares. ER is the Efficiency Ratio which equals Non-Interest Expense divided by } \\
\text { the sum of Non-Interest Income and Net Interest Income. PerCap stands for Percent Captured and is } \\
\text { the number of CU members divided by the number of potential CU members. LnAssets is the log of } \\
\text { the dollar amount of assets at the CU. NWR, Net Worth Ratio, is the ratio of the net worth of the CU } \\
\text { to the total assets of the CU. NIIPortion is the portion of Non-Interest Income to total income. } \\
\text { StateIns is a dummy variable equal to one if the CU is state-chartered and federally insured. } \\
\text { StateUnins is a dummy variable equal to one if the CU is state-chartered and not federally insured. } \\
\text { All other CUs are federally chartered and insured. UninsDep is the ratio of total uninsured shares and } \\
\text { deposits to total assets. OneMinTL is the amount of assets outside of total loans and leases divided } \\
\text { by total assets. Risk is the amount of delinquent loans divided by total assets for the CU. Recover is }\end{array}$} \\
\hline
\end{tabular}


year-to-date recoveries of loan losses less the year-to-date charge offs of loans divided by total assets. REG1, REG2, etc. are dummy variables for geographic regions used by CUNA where the base region is REG1. Year dummies $(2002,2003$, etc.) are equal to one for the year in which the data point is drawn from and zero otherwise where 2001 is the base year. The HCCM T-Value column provides t-values using Heteroscedasticity Consistent Covariance Matrix (HCCM) Estimation. This procedure is done in White (1980).

TABLE 4

FACTORS IMPACTING THE DIVIDEND PERCENT RETURN, DPR, 2008 - 2009

\begin{tabular}{|c|c|c|c|c|}
\hline Variable & Coefficient & T-Value & HCCM T-Value & VIF \\
\hline Intercept & 0.00465 & 7.51 & 5.38 & 0 \\
\hline LagDPR & 0.73253 & 184.66 & 103.50 & 1.323 \\
\hline ER & -0.00077 & -2.66 & -1.93 & 1.220 \\
\hline PerCap & 0.00009 & 0.62 & 0.56 & 1.317 \\
\hline LnAssets & 0.000004 & 0.13 & 0.10 & 2.117 \\
\hline NWR & -0.000004 & -0.47 & -0.42 & 1.439 \\
\hline NIIPortion & -0.00008 & -0.21 & -0.18 & 1.707 \\
\hline StateIns & -0.00050 & -6.51 & -5.94 & 1.226 \\
\hline StateUnins & -0.00017 & -0.62 & -0.43 & 1.055 \\
\hline UninsDep & 0.00331 & 2.74 & 2.50 & 1.592 \\
\hline OneMinTL & -0.00279 & -12.53 & -10.94 & 1.329 \\
\hline Risk & 0.01339 & 3.91 & 3.11 & 1.267 \\
\hline Recover & 0.05763 & 6.67 & 5.71 & 1.310 \\
\hline REG2 & 0.00045 & 3.76 & 3.90 & 1.711 \\
\hline REG3 & 0.00038 & 3.26 & 3.21 & 1.946 \\
\hline REG4 & 0.00022 & 2.07 & 2.02 & 2.148 \\
\hline REG5 & 0.00001 & 0.07 & 0.07 & 1.679 \\
\hline 2009 & -0.00361 & -45.53 & -42.41 & 1.378 \\
\hline & \multicolumn{4}{|c|}{$\mathrm{N}=11,713$} \\
\hline & \multicolumn{4}{|c|}{$\mathrm{R}^{2}=0.8196$} \\
\hline & \multicolumn{4}{|c|}{ F-Value $=3,124.50$} \\
\hline \multicolumn{5}{|c|}{$\begin{array}{l}\text { The dividend percent return, DPR, examined is the total dividend paid on shares divided by the } \\
\text { total dollar amount of shares. ER is the Efficiency Ratio which equals Non-Interest Expense } \\
\text { divided by the sum of Non-Interest Income and Net Interest Income. PerCap stands for Percent } \\
\text { Captured and is the number of CU members divided by the number of potential CU members. } \\
\text { LnAssets is the log of the dollar amount of assets at the CU. NWR, Net Worth Ratio, is the } \\
\text { ratio of the net worth of the CU to the total assets of the CU. NIIPortion is the portion of Non- } \\
\text { Interest Income to total income. StateIns is a dummy variable equal to one if the CU is state- } \\
\text { chartered and federally insured. StateUnins is a dummy variable equal to one if the CU is state- } \\
\text { chartered and not federally insured. All other CUs are federally chartered and insured. } \\
\text { UninsDep is the ratio of total uninsured shares and deposits to total assets. OneMinTL is the } \\
\text { amount of assets outside of total loans and leases divided by total assets. Risk is the amount of } \\
\text { delinquent loans divided by total assets for the CU. Recover is year-to-date recoveries of loan } \\
\text { losses less the year-to-date charge offs of loans divided by total assets. REG1, REG2, etc. are } \\
\text { dummy variables for geographic regions used by CUNA where the base region is REG1. The } \\
\text { year dummy for } 2009 \text { is equal to one for the year } 2009 \text { and zero otherwise where 2008 is the } \\
\text { base year. The HCCM T-Value column provides t-values using Heteroscedasticity Consistent } \\
\text { Covariance Matrix (HCCM) Estimation. This procedure is done in White (1980). }\end{array}$} \\
\hline
\end{tabular}




\section{Factors Affecting DIFF for the Full Sample Period}

Table 5 shows the results for the first regression using the entire length of the sample from 2000 to 2015 where DIFF is used to measure benefits to CU members. Recall that DIFF measures the difference between the return on earned on lending less the return paid on shares and deposits. This measure of performance is advocated by Taylor (1971). Recall that as DIFF increases the difference between the return on earned on lending and the return paid in the form of dividends on shares is growing wider, decreasing benefits to $\mathrm{CU}$ members.

TABLE 5

FACTORS IMPACTING THE RATE DIFFERENTIAL, DIFF, 2000 - 2015

\begin{tabular}{|c|c|c|c|c|}
\hline Variable & Coefficient & T-Value & HCCM T-Value & VIF \\
\hline Intercept & 0.03846 & 89.68 & 10.04 & 0 \\
\hline LagDIFF & 0.65745 & 334.09 & 18.46 & 1.584 \\
\hline PerCap & -0.00039 & -3.73 & -3.32 & 1.317 \\
\hline LnAssets & -0.00135 & -61.31 & -9.05 & 2.529 \\
\hline NWR & 0.00011 & 19.12 & 9.58 & 1.346 \\
\hline NIIPortion & 0.00880 & 27.42 & 5.75 & 1.931 \\
\hline StateIns & -0.00024 & -4.29 & -4.33 & 1.127 \\
\hline StateUnins & 0.00018 & 0.86 & 0.90 & 1.039 \\
\hline UninsDep & -0.00630 & -6.33 & -6.20 & 1.609 \\
\hline OneMinTL & 0.00783 & 46.20 & 13.44 & 1.332 \\
\hline Risk & 0.05828 & 21.18 & 13.42 & 1.282 \\
\hline Recover & -0.51667 & -69.51 & -16.72 & 1.269 \\
\hline REG2 & 0.00019 & 2.04 & 1.68 & 1.751 \\
\hline REG3 & 0.00038 & 4.25 & 4.34 & 1.884 \\
\hline REG4 & -0.00014 & -1.71 & -1.61 & 2.080 \\
\hline REG5 & 0.00011 & 1.16 & 1.29 & 1.706 \\
\hline REG6 & 0.00049 & 3.09 & 2.87 & 1.333 \\
\hline REG8 & 0.00504 & 1.87 & 4.55 & 1.003 \\
\hline 2002 & 0.00037 & 3.00 & 1.17 & 1.802 \\
\hline 2003 & -0.00312 & -24.83 & -6.85 & 1.818 \\
\hline 2004 & -0.00620 & -48.03 & -13.49 & 1.841 \\
\hline 2005 & -0.00922 & -71.22 & -25.33 & 1.805 \\
\hline 2006 & -0.00839 & -64.40 & -36.68 & 1.773 \\
\hline 2007 & -0.00710 & -53.71 & -43.61 & 1.753 \\
\hline 2008 & -0.00361 & -26.06 & -23.06 & 1.643 \\
\hline 2009 & -0.00255 & -18.01 & -17.44 & 1.674 \\
\hline 2010 & -0.00096 & -6.58 & -3.50 & 1.607 \\
\hline 2011 & -0.00291 & -19.77 & -7.19 & 1.649 \\
\hline 2012 & -0.00460 & -31.02 & -10.79 & 1.676 \\
\hline 2013 & -0.00601 & -39.91 & -16.37 & 1.646 \\
\hline 2014 & -0.00610 & -40.59 & -21.06 & 1.642 \\
\hline 2015 & -0.00607 & -40.31 & -25.43 & 1.632 \\
\hline & \multicolumn{4}{|c|}{$\mathrm{N}=97,956$} \\
\hline & \multicolumn{4}{|c|}{$\mathrm{R}^{2}=0.7348$} \\
\hline & \multicolumn{4}{|c|}{ F-Value $=8,751.66$} \\
\hline
\end{tabular}


(Dividends on Shares plus Interest on Deposits divided by Total Shares and Deposits). PerCap stands for Percent Captured and is the number of $\mathrm{CU}$ members divided by the number of potential $\mathrm{CU}$ members. LnAssets is the log of the dollar amount of assets at the CU. NWR, Net Worth Ratio, is the ratio of the net worth of the CU to the total assets of the CU. NIIPortion is the portion of NonInterest Income to total income. StateIns is a dummy variable equal to one if the CU is statechartered and federally insured. StateUnins is a dummy variable equal to one if the CU is statechartered and not federally insured. All other CUs are federally chartered and insured. UninsDep is the ratio of total uninsured shares and deposits to total assets. OneMinTL is the amount of assets outside of total loans and leases divided by total assets. Risk is the amount of delinquent loans divided by total assets for the CU. Recover is year-to-date recoveries of loan losses less the year-todate charge offs of loans divided by total assets. REG1, REG2, etc. are dummy variables for geographic regions used by CUNA where the base region is REG1. Year dummies $(2002,2003$, etc.) are equal to one for the year in which the data point is drawn from and zero otherwise where 2001 is the base year. The HCCM T-Value column provides t-values using Heteroscedasticity Consistent Covariance Matrix (HCCM) Estimation. This procedure is done in White (1980).

Most of the results from Table 2 using DPR carry over into Table 5 using DIFF with a couple of exceptions. While the coefficient of NWR indicates decreasing leverage is related to decreasing levels of benefits in both regressions, NWR is only marginally significant in the analysis of DPR, but it is significant with a p-value of less than 0.0001 in the analysis of DIFF. Second, in the DIFF regression, Risk is positive and significant. Thus, while the hypothesis that a higher level of risk in the form of more delinquent loans would also indicate poor lending decisions and practices which may hinder benefits to members was rejected when looking at DPR, the hypothesis is supported using DIFF.

\section{Factors Affecting DIFF for the Non-crisis and Crisis Periods}

For the two subgroups examined, the only significant difference is for the crisis period. In the full sample, PerCap is negative and significant. However, in the crisis period, PerCap is positive and significant. This may suggest that while more competitive CUs will provide more benefits to their members during "normal" times, perhaps having more market power and protection is better during downturns. 
TABLE 6

FACTORS IMPACTING THE RATE DIFFERENTIAL, DIFF, $2001-2007,2010$ - 2015

\begin{tabular}{|c|c|c|c|c|}
\hline Variable & Coefficient & T-Value & HCCM T-Value & VIF \\
\hline Intercept & 0.03890 & 84.82 & 9.93 & 0 \\
\hline LagDIFF & 0.65569 & 310.68 & 16.36 & 1.568 \\
\hline PerCap & -0.00055 & -4.84 & -4.35 & 1.321 \\
\hline LnAssets & -0.00137 & -57.77 & -8.34 & 2.549 \\
\hline NWR & 0.00011 & 17.70 & 8.87 & 1.332 \\
\hline NIIPortion & 0.00933 & 26.89 & 5.53 & 1.959 \\
\hline StateIns & -0.00020 & -3.34 & -3.47 & 1.125 \\
\hline StateUnins & 0.00033 & 1.46 & 1.52 & 1.038 \\
\hline UninsDep & -0.00491 & -4.53 & -4.22 & 1.613 \\
\hline OneMinTL & 0.00779 & 42.79 & 11.22 & 1.333 \\
\hline Risk & 0.05992 & 20.10 & 12.40 & 1.284 \\
\hline Recover & -0.53195 & -65.41 & -14.74 & 1.253 \\
\hline REG2 & 0.00006 & 0.62 & 0.50 & 1.759 \\
\hline REG3 & 0.00032 & 3.37 & 3.45 & 1.884 \\
\hline REG4 & -0.00034 & -3.84 & -3.64 & 2.080 \\
\hline REG5 & 0.00001 & 0.08 & 0.08 & 1.713 \\
\hline REG6 & 0.00035 & 2.16 & 1.97 & 1.358 \\
\hline REG8 & 0.00497 & 1.83 & 4.40 & 1.003 \\
\hline 2002 & 0.00037 & 2.97 & 1.08 & 1.781 \\
\hline 2003 & -0.00313 & -24.63 & -6.26 & 1.804 \\
\hline 2004 & -0.00622 & -47.67 & -12.31 & 1.830 \\
\hline 2005 & -0.00926 & -70.73 & -23.24 & 1.793 \\
\hline 2006 & -0.00842 & -64.04 & -34.65 & 1.760 \\
\hline 2007 & -0.00716 & -53.52 & -43.06 & 1.743 \\
\hline 2010 & -0.00100 & -6.78 & -3.46 & 1.608 \\
\hline 2011 & -0.00294 & -19.72 & -6.69 & 1.652 \\
\hline 2012 & -0.00463 & -30.79 & -9.99 & 1.683 \\
\hline 2013 & -0.00605 & -39.61 & -15.16 & 1.654 \\
\hline 2014 & -0.00614 & -40.33 & -19.72 & 1.649 \\
\hline 2015 & -0.00612 & -40.10 & -24.17 & 1.638 \\
\hline \multicolumn{5}{|c|}{$\mathrm{N}=86,243$} \\
\hline & \multicolumn{4}{|c|}{$\mathrm{R}^{2}=0.733$} \\
\hline \multicolumn{5}{|c|}{\begin{tabular}{c|c} 
& F-Value $=8,159.56$ \\
\end{tabular}} \\
\hline \multicolumn{5}{|c|}{$\begin{array}{l}\text { The rate differential, DIFF, between the rate of interest received on loans (Interest on Loans less } \\
\text { Interest Refunded divided by Total Loans and Leases) and the interest paid on shares and deposits } \\
\text { (Dividends on Shares plus Interest on Deposits divided by Total Shares and Deposits). PerCap stands } \\
\text { for Percent Captured and is the number of CU members divided by the number of potential CU } \\
\text { members. LnAssets is the log of the dollar amount of assets at the CU. NWR, Net Worth Ratio, is the } \\
\text { ratio of the net worth of the CU to the total assets of the CU. NIIPortion is the portion of Non-Interest } \\
\text { Income to total income. StateIns is a dummy variable equal to one if the CU is state-chartered and } \\
\text { federally insured. StateUnins is a dummy variable equal to one if the CU is state-chartered and not } \\
\text { federally insured. All other CUs are federally chartered and insured. UninsDep is the ratio of total } \\
\text { uninsured shares and deposits to total assets. OneMinTL is the amount of assets outside of total loans } \\
\text { and leases divided by total assets. Risk is the amount of delinquent loans divided by total assets for } \\
\text { the CU. Recover is year-to-date recoveries of loan losses less the year-to-date charge offs of loans }\end{array}$} \\
\hline
\end{tabular}


divided by total assets. REG1, REG2, etc. are dummy variables for geographic regions used by CUNA where the base region is REG1. Year dummies (2002, 2003, etc.) are equal to one for the year in which the data point is drawn from and zero otherwise where 2001 is the base year. The HCCM TValue column provides t-values using Heteroscedasticity Consistent Covariance Matrix (HCCM) Estimation. This procedure is done in White (1980).

TABLE 7

FACTORS IMPACTING THE RATE DIFFERENTIAL, DIFF, 2008 - 2009

\begin{tabular}{|c|c|c|c|c|}
\hline Variable & Coefficient & T-Value & HCCM T-Value & VIF \\
\hline Intercept & 0.03140 & 26.74 & 7.07 & 0 \\
\hline LagDIFF & 0.67229 & 123.88 & 16.30 & 1.556 \\
\hline PerCap & 0.00071 & 2.53 & 2.59 & 1.292 \\
\hline LnAssets & -0.00120 & -19.92 & -6.60 & 2.459 \\
\hline NWR & 0.00010 & 6.44 & 5.13 & 1.441 \\
\hline NIIPortion & 0.00487 & 5.83 & 2.59 & 1.749 \\
\hline StateIns & -0.00050 & -3.29 & -2.80 & 1.142 \\
\hline StateUnins & -0.00060 & -1.16 & -1.23 & 1.052 \\
\hline UninsDep & -0.01440 & -5.83 & -6.88 & 1.587 \\
\hline OneMinTL & 0.00843 & 18.36 & 14.62 & 1.344 \\
\hline Risk & 0.05241 & 7.47 & 5.45 & 1.261 \\
\hline Recover & -0.4520 & -25.04 & -15.12 & 1.358 \\
\hline REG2 & 0.00100 & 4.05 & 3.40 & 1.698 \\
\hline REG3 & 0.00078 & 3.35 & 3.20 & 1.895 \\
\hline REG4 & 0.00118 & 5.44 & 5.40 & 2.078 \\
\hline REG5 & 0.00079 & 3.17 & 3.70 & 1.673 \\
\hline 2009 & 0.00100 & 6.28 & 5.35 & 1.311 \\
\hline & \multicolumn{4}{|c|}{$\mathrm{N}=11,713$} \\
\hline & \multicolumn{4}{|c|}{$\mathrm{R}^{2}=0.7501$} \\
\hline & \multicolumn{4}{|c|}{ F-Value $=2,194.34$} \\
\hline
\end{tabular}

The rate differential, DIFF, between the rate of interest received on loans (Interest on Loans less Interest Refunded divided by Total Loans and Leases) and the interest paid on shares and deposits (Dividends on Shares plus Interest on Deposits divided by Total Shares and Deposits). PerCap stands for Percent Captured and is the number of $\mathrm{CU}$ members divided by the number of potential $\mathrm{CU}$ members. LnAssets is the log of the dollar amount of assets at the CU. NWR, Net Worth Ratio, is the ratio of the net worth of the $\mathrm{CU}$ to the total assets of the CU. NIIPortion is the portion of Non-Interest Income to total income. StateIns is a dummy variable equal to one if the $\mathrm{CU}$ is state-chartered and federally insured. StateUnins is a dummy variable equal to one if the CU is state-chartered and not federally insured. All other CUs are federally chartered and insured. UninsDep is the ratio of total uninsured shares and deposits to total assets. OneMinTL is the amount of assets outside of total loans and leases divided by total assets. Risk is the amount of delinquent loans divided by total assets for the CU. Recover is year-to-date recoveries of loan losses less the year-to-date charge offs of loans divided by total assets. REG1, REG2, etc. are dummy variables for geographic regions used by CUNA where the base region is REG1. The year dummy for 2009 is equal to one for 2009 and zero otherwise where 2008 is the base year. The HCCM T-Value column provides t-values using Heteroscedasticity Consistent Covariance Matrix (HCCM) Estimation. This procedure is done in White (1980). 


\section{CONCLUSION}

While CUs are chosen as financial intermediaries by over 110.6 million members, roughly over onethird of the U.S. population, the performance and workings of these small (in terms of asset size) institutions have received a relatively small amount of research compared to their cousins, banks. Perhaps this is because of one of the distinguishing features of CUs, namely their not-for-profit, collective nature. Because they are not profit-driven, the usual analysis of examining ROA, ROE, or some measure of profits is not an option for CUs. Since CUs are cooperatives owned by their members, an appropriate measure to use would be the benefits the CU provides to its members.

In this paper, two measures are used to measure those benefits. The first measure is the dividend percent return to shareholders. If Smith et.al. (1981) are correct and borrowers and savers are treated equally with benefits, dividend performance should approximate benefits given to borrowers as well. Thus, just looking at the dividend percent return can give us an approximation of CU benefits provided to both savers and borrowers. The second measure is the difference between the return on earned on lending less the return paid in the form of dividends on shares. This measures performance as advocated by Taylor (1971). Since borrowers and shareholders are members, a smaller gap implies benefits being shared by savers and borrowers.

While CUs are separate and distinct from banks, they do function much like a bank in terms of the products and services offered. That is why, in this paper, variables that have been found useful in measuring bank performance and CU performance have been adopted to explain CU performance.

The findings of this paper indicate that CUs provide higher levels of benefits when they are more efficient, more competitive, are larger in terms of total assets, utilize less non-interest income focusing more on lending, have higher levels of uninsured deposits which allows for more market discipline, and are better screeners and monitors of their borrowers when measured by their ability to collect on delinquent loans. There were a couple of ambiguous findings in the results, however. While the relative risk of the $\mathrm{CU}$ (when measured by delinquent loans) was negatively related to member benefits when measured by DIFF, the opposite was the case when benefits were measured by DPR.

\section{ENDNOTES}

1. Credit Union National Association. (n.d.) U.S. Credit Union Profile. https://www.cuna.org/Research-AndStrategy/Credit-Union-Data-And-Statistics/; Accessed 2017.

2. An outlier was considered: 1) a data point with an ER above 1 or below $-1,2$ ) a ROA above $+10 \%$ or below $-10 \%, 3$ ) a dividend payout percent over $100 \%, 4$ ) a Risk above $7 \%, 5$ ) a NWR above $35 \%, 6$ ) a NIIPortion above $50 \%$ or below $-30 \%, 7$ ) UnInsDep above $16 \%, 8$ ) Recover above $2 \%$ or below $-2.5 \%$, or 9) a DIFF greater than $12 \%$ or lower than $2 \%$. In general, if an observation was about three standard deviations or more from the mean, it was removed from the sample.

3. Covariance and correlation matrices were created for all input variables used in the regressions but are not reported here to save space. However, in the correlation matrix, the highest value between any two variables was 0.413408 and the lowest value was -0.38907 . Thus, the correlation between the variables does not appear to be a concern.

4. Tests for heteroscedasticity show heteroscedasticity within the data in the regressions. In the table for each regression, t-statistics are given using Heteroscedasticity Consistent Covariance Matrix (HCCM) Estimation consistent with White (1980) along with the regular t-statistics. Overall, the significance of each variable remains the same.

\section{REFERENCES}

Akhigbe, A., \& McNulty, J. (2005). Profit efficiency sources and differences among small and large US commercial banks. Journal of Economics and Finance, 29(3), 289-299. 
Akhigbe, A., McNulty, J. E., \& Stevenson, B. A. (2017). Does the form of ownership affect firm performance? Evidence from US bank profit efficiency before and during the financial crisis. The Quarterly Review of Economics and Finance, 64, 120-129.

Akhigbe, A., \& Stevenson, B. A. (2010). Profit efficiency in US BHCs: Effects of increasing nontraditional revenue sources. The Quarterly Review of Economics and Finance, 50(2), 132-140.

Baele, L., De Jonghe, O., \& Vander Vennet, R. (2007). Does the stock market value bank diversification? Journal of Banking \& Finance, 31(7), 1999-2023.

Baer, H., \& Brewer, E. (1986). Uninsured deposits as a source of market discipline: Some new evidence. Economic Perspectives, 10(5), 23-31.

Credit Union National Association. (n.d.) Market Share of Depository Institution Assets. Retrieved from https://www.cuna.org/Research-And-Strategy/Credit-Union-Data-And-Statistics/

Credit Union National Association. (n.d.) U.S. Credit Union Profile. Retrieved from https://www.cuna.org/Research-And-Strategy/Credit-Union-Data-And-Statistics/

Esho, N., Kofman, P., \& Sharpe, I. G. (2005). Diversification, fee income, and credit union risk. Journal of Financial Services Research, 27(3), 259-281.

Ferguson, M. F., \& Stevenson, B. A. (2014). Depositor discipline and the bank's incentive to monitor. Journal of Financial Economic Policy, 6(2), 98-111.

Frame, W. S., Karels, G. V., \& McClatchey, C. A. (2003). Do credit unions use their tax advantage to benefit members? Evidence from a cost function. Review of Financial Economics, 12(1), 35-47.

Fried, H. O., Lovell, C. K., \& Eeckaut, P. V. (1993). Evaluating the performance of US credit unions. Journal of Banking \& Finance, 17(2-3), 251-265.

Goddard, J., McKillop, D., \& Wilson, J. O. (2008a). The diversification and financial performance of US credit unions. Journal of Banking \& Finance, 32(9), 1836-1849.

Goddard, J., McKillop, D., \& Wilson, J. O. (2008b). What drives the performance of cooperative financial institutions? Evidence for US credit unions. Applied Financial Economics, 18(11), 879893.

Karels, G. V., \& McClatchey, C. A. (1999). Deposit insurance and risk-taking behavior in the credit union industry. Journal of Banking \& Finance, 23(1), 105-134.

Malikov, E., Zhao, S., \& Kumbhakar, S. C. (2017). Economies of diversification in the US credit union sector. Journal of Applied Econometrics, 32(7), 1329-1347.

Murray, J. D., \& White, R. W. (1980). Economies of Scale and Deposit-Taking Financial Institutions in Canada: Study of British Columbia Credit Unions. Journal of Money, Credit and Banking, 12(1), 58-70.

Smith, D. J. (1984). A theoretic framework for the analysis of credit union decision making. The Journal of Finance, 39(4), 1155-1168.

Smith, D. J., Cargill, T. F., \& Meyer, R. A. (1981). An economic theory of a credit union. The Journal of Finance, 36(2), 519-528.

Stiroh, K. J. (2004). Do community banks benefit from diversification? Journal of Financial Services Research, 25(2-3), 135-160.

Stiroh, K. J., \& Rumble, A. (2006). The dark side of diversification: The case of US financial holding companies. Journal of banking \& finance, 30(8), 2131-2161.

Taylor, R. A. (1971). The credit union as a cooperative institution. Review of social economy, 29(2), 207217.

Wheelock, D. C., \& Wilson, P. W. (2011). Are credit unions too small? Review of Economics and Statistics, 93(4), 1343-1359.

Wheelock, D. C., \& Wilson, P. W. (2013). The evolution of cost-productivity and efficiency among US credit unions. Journal of Banking \& Finance, 37(1), 75-88.

White, H. (1980). A heteroskedasticity-consistent covariance matrix estimator and a direct test for heteroskedasticity. Econometrica: Journal of the Econometric Society, 817-838.

Wilcox, J. A. (2006). Performance divergence of large and small credit unions. FRBSF Economic Letter. 